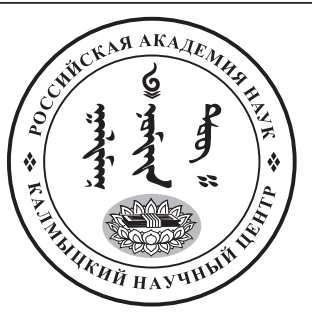

Published in the Russian Federation

Oriental Studies (Previous Name: Bulletin of the Kalmyk Institute

for Humanities of the Russian Academy of Sciences)

Has been issued as a journal since 2008

ISSN: 2619-0990; E-ISSN: 2619-1008

Vol. 13, Is. 6, pp. 1558-1567, 2020

DOI: $10.22162 / 2619-0990-2020-52-6-1558-1567$

Journal homepage: https://kigiran.elpub.ru

УДК $294.321+39$

DOI: $10.22162 / 2619-0990-2020-52-6-1558-1567$

\title{
О новом источнике «устной истории» бурят о паломничестве по Внутренней Азии в начале XX в.
}

\section{Саяна Баировна Намсараева}

${ }^{1}$ Калмыцкий научный центр РАН (д. 8, ул. им. И. К. Илишкина, 358000 Элиста, Российская Федерация)

кандидат исторических наук, доцент, ведущий научный сотрудник

iD 0000-0003-4670-9448. E-mail: sn444@cam.ac.uk

\author{
(C) КалмНЦ РАН, 2020 \\ (C) Намсараева С. Б., 2020
}

Аннотация. Введение. В научной литературе по буддийскому паломничеству основное внимание уделяется объектам паломничества — известным монастырям, биографиям выдающихся буддийских деятелей и линиям перерождений, основанных ими, в то время как действующие субъекты (aкmopы) паломничества — сами паломники-миряне (монг. хара хүн) зачастую остаются вне поля зрения исследователей. Имеющиеся письменные источники в жанре религиозных «хождений» к буддийским святыням Внутренней Азии были написаны по большей части духовными лицами - ламами. Тем не менее часть пласта «устных историй» бурят о хождениях в Тибет в начале прошлого века была записана позже подвижниками, к числу которых относятся Б. Б. Барадийн и другие энтузиасты. Цель данной статьи - введение в научный оборот одну из таких записей, сделанную сельским учителем и краеведом Б. Б. Намсараевым в 1968 г. на бурятском языке, по устным историям старейшины села Судунтуй Читинской области Бато Бадмаева о его путешествии к святыням Тибета в 1901-1904 гг. Результаты. Рассказ мирянина о его паломничестве, изложенный в стиле намтар ('автобиография'), является уникальным источником сведений о широкой практике бурятского паломничества к буддийским святыням Внутренней Азии, рассказанных самим участником - актором паломничества. Несмотря на незамысловатость повествования и фольклорный характер с полуфантастическими элементами (встреча со снежным человеком йети), эти рассказы несут в себе ценные сведения, которые были упущены в путевых дневниках других профессиональных путешественников и хождениях лам. В силу опыта именно пешего паломничества рассказы Бато описывают инфраструктуру, возникшую вдоль трансграничного маршрута, призванную обслуживать как пеших паломников, так и караваны: те самые семьи монголов и тибетцев, которые обеспечивали паломников берестяными коробами с шестами, прутьями, емкостями для воды для перехода пустыни и т. д. Переиздание рассказов Бато Бадмаева о хождениях в Тибет и Монголию дало 
возможность ввести в научный оборот этот уникальный источник и сделать его доступным широкой публике.

Ключевые слова: «устные истории», жанр «хождений» в Тибет, бурятское паломничество, паломники-миряне, снежный человек йети, Урга, Лхаса, Забайкалье, Богдо-геген

Благодарность. Автор благодарит Ц. П. Ванчикову за помощь в работе с фондами ЦВРК ИМБТ СО РАН. Исследование выполнено при финансовой поддержке гранта в форме субсидии из федерального бюджета, выделяемой для государственной поддержки научных исследований, проводимых под руководством ведущего ученого (проект «От палеогенетики до культурной антропологии: комплексное интердисциплинарное исследование традиций народов трансграничных регионов: миграции, межкультурное взаимодействие и картина мира»). Материалы статьи апробированы на Международной научной онлайн-конференции «Монголоведение в начале XXI в.: современное состояние и перспективы развития - II», проведенной при финансовой поддержке РФФИ (проект № 20-09-22004) и частичной поддержке гранта Правительства РФ (№ 075-15-2019-1879).

Для цитирования: Намсараева С. Б. О новом источнике «устной истории» бурят о паломничестве по Внутренней Азии в начале XX в. // Oriental Studies. 2020. Т. 13. № 6. С. 1558-1567. DOI: $10.22162 / 2619-0990-2020-52-6-1558-1567$

UDC $294.321+39$

DOI: $10.22162 / 2619-0990-2020-52-6-1558-1567$

\title{
Buryat Oral Histories on Inner Asian Pilgrimage: Introducing a New Source
}

\author{
Sayana B. Namsaraeva ${ }^{1}$ \\ ${ }^{1}$ Kalmyk Scientific Center of the RAS (8, Ilishkin St., Elista 358000, Russian Federation) \\ Cand. Sc. (History), Leading Research Associate \\ iD 0000-0003-4670-9448. E-mail: sn444@cam.ac.uk \\ (C) KalmSC RAS, 2020 \\ (C) Namsaraeva S. B., 2020
}

\begin{abstract}
Introduction. Research on Buryat and Kalmyk pilgrimage to Buddhist worshiping sites in Tibet and wider in Inner Asia at the late imperial period mostly focuses on biographies and travel writings of Buddhist clergy, while experience of ordinary pilgrims - especially of the lay people (Mong. khara khün) who were actors of this social phenomena - received limited attention. However, some of the Buryat 'oral histories' about long distance travels to Tibet were recorded later by Buryat intellectuals (e. g., B. B. Baradiin) to name but a few. Goals. The article aims to introduce one such record made in 1968 by a rural community school teacher and amateur historian B. B. Namsaraev. Results. The latter wrote down a life story (Mong. namtar) of Bato Badmaev, an elder from the village of Suduntui, about his pilgrimage to Tibet between 1901 and 1904. This travelogue by a lay person presents unique first-hand observations about hardships of the long distance foot pilgrimage to worshiping places in Urga, Amdo and Tibet - a wide social phenomenon among Buryats at the beginning of the $20^{\text {th }}$ century. This 'oral history' together with extensive information about infrastructure along the pilgrim routes (Mongolian and Tibetan families hosting pilgrims and providing meals to them, travel tips they shared of how to pass the most dangerous hostile deserts and mountain passes, encountering a yeti snowman (Mong. almaz), etc.) contain emotional remarks about things experienced and bodily hardships pilgrims faced (thirst, physical exhaustion, extreme temperatures, and so on) - aspects which are not covered in travelogues of Buddhist clergy and professional explorers (e. g., merchants, military specialists) who were in much more privileged travel conditions hiring horses and camels to carry their goods and belongings. Therefore, the recent publication (2012) of this unique travelogue made it more accessible and available to a wider a udience.
\end{abstract}


Keywords: 'oral histories', travelogues, pilgrimage to Tibet, Buryat lay pilgrims, yeti snowman, Urga, Lhasa, Transbaikal Region, Bogdo Gegeen

Acknowledgements. The author expresses gratitude to Ts. Vanchikova for the rendered assistance in exploring collections of the Center of Oriental Manuscripts and Xylographs affiliated to the Institute for Mongolian, Buddhist and Tibetan Studies (Siberian Branch of the RAS). The reported study was funded by government grant in the form of federal budget subsidy aimed to support scientific research directed by the Leading Scientist — project name 'From Paleogenetics to Cultural Anthropology: Comprehensive Interdisciplinary Research of Peoples and Traditions of Cross-Border Regions Migrations, Cross-Cultural Interactions and Worldviews'. The article was presented at the International scientific online conference 'Mongolian Studies at the Beginning of the $21^{\text {st }}$ Century: Current State and Development Prospects - II' funded by RFBR (project no. 20-09-22004) and Government of Russia (grant no. 075-15-2019-1879).

For citation: Namsaraeva S. B. Buryat Oral Histories on Inner Asian Pilgrimage: Introducing a New Source. Oriental Studies. 2020. Vol. 13(6): 1558-1567. (In Russ.). DOI: 10.22162/2619-0990-202052-6-1558-1567

\section{है}

\section{Введение}

Изабель Шарлё в своей недавно опубликованной книге «Кочевники в паломничестве: монголы в Утайшане (Китай), 1800-1940» («Nomads on Pilgrimage: Mongols on Wutaishan (China), 1800-1940») справедливо отметила, что в целом в научной литературе по буддийскому паломничеству больше внимания уделяется объектам паломничества - известным монастырям, биографиям выдающихся буддийских деятелей и линиям перерождений, основанных ими, в то время как действующие субъекты (aкmopbl) паломничества - сами паломники - зачастую остаются вне поля зрения исследователей [Charleux 2015: XI]. У этой «несправедливости» есть свое объяснение: простые паломники-миряне (монг. хара хүн) практически не оставляли письменных записей о своих странствиях в далекие земли, а их рассказы лишь отчасти сохранились в пластах народных преданий в жанре «устных историй». Те немногие письменные источники в жанре религиозных «хождений» к буддийским святыням Внутренней Азии, о которых мы знаем, были написаны по большей части духовными лицами - монгольскими, бурятскими и калмыцкими монахами, оставившими свои записи в виде различных географических описаний, в основном, описаний монастырей и святынь Утайшаня и Тибета [Сазыкин 1989: 26-36], либо как жития и авто/ биографические сочинения (монг. намтар) [Дугар-Нимаев 1974: 148; Ванчикова 1995:
33-43] $]^{1}$. А. Г. Сазыкин относит начало распространения сочинений географического характера на монгольском языке к периоду не ранее второй половины XVII в., а записи калмыцких и бурятских паломников начинают появляться только со второй половины XVIII в. [Сазыкин 1989: 117].

Трансграничные путешествия российских буддистов с северной периферии буддийского мира (Восточной Сибири) к буддийским святыням Монголии и Тибета начались, если судить по дневниковым записям хамбо-ламы Дамба-Доржи Заяева и «Сказанию о хождении в Тибетскую страну Мало-Дорботского База-Бакши» Менкеджуева, с середины XVIII в. К концу XIX в. проторенными тропами через Монголию в Тибет ходили уже сотни калмыцких и бурятских паломников. Как писал А. М. Позднеев, «...и теперь буряты целыми десятками ежегодно уходят в Тибет для поклонения тамошним святыням, принятия посвящений и усовершенствования в науках» [Позднеев

1 Причем, по мнению Ц. П. Ванчиковой, «Биографические сочинения, написанные бурятскими ламами, отличаются по форме от монгольских намтаров. Их можно уже назвать биографиями в современном понимании этого слова. Они конкретно излагают действительные события жизни, в них отсутствуют такие характерные для житий элементы, как описания всевозможных чудес, предсказания и сообщения о сверхъестественных способностях буддистских монахов» [Ванчикова 1995: 35]. 
1897: III]. Именно в период начиная с конца XIX в. до 1917 г. было создано большинство известных нам записей в жанре хождений духовными лицами - калмыцкими и бурятскими монахами, среди которых надо назвать сочинения Агвана Доржиева, Лубсан Мицжэд-Доржэ, Чойнзон-Доржи Иролтуева, Бааза-багши Уланова и многих других. Помимо этих вышеупомянутых авторских сочинений, есть некоторое количество сочинений лам, написанных на старомонгольском языке, авторство коих еще не атрибутировано, хранящихся в фондах Центра восточных рукописей и ксилографов Института монголоведения, буддологии и тибетологии СО РАН (ЦВРК ИМБТ СО РАН) в Улан-Удэ и в архиве монгольского фонда Института восточных рукописей РАН в Санкт-Петербурге [Сазыкин 1988]².

Путевые записи профессиональных путешественников: европейских миссионеров, торговцев и военных на службе властей (к примеру, колониальных властей Великобритании в Индии или экспедиции под эгидой императорского Русского Географического общества, и прочее) имели свои особенности, так как имели не религиозный, светский характер и несли в себе сведения иного характера, полезные для дальнейшей имперской экспансии, к примеру, описание торговой и дорожной инфраструктуры региона, с указанием расстояний между населенными пунктами, социальное устройство местных народов, и т. д. М. Л. Пратт образно назвала эту точку зрения, которая присутствует в подобных путевых записях по дальним колониям и полуколониальным землям европейских путешественников, как «imperial eyes», что можно перевести как «имперский взгляд» [Pratt 2008]. Результаты путешествий российских географов и исследователей, таких как Б. Барадийн, П. К. Козлов, О. Норзунов, Г. Цыбиков к буддийским святыням Амдо и Тибета уже введены в научный оборот и хорошо известны.

В рамках данной статьи, восполняя пробел, отмеченный Изабель Шарлё, остано-

2 В своей более поздней статье 1994 г. А. Г. Сазыкин опубликовал имена некоторых авторов, таких как гэлун Доржи, Лубсан Лудуб Андагаев, включая имена лам, сочинения которых были утрачены [Сазыкин 1994: 26-35]. вимся подробнее на характеристике нового источника - воспоминаниях одного из мирян-паломников, записанных в жанре «устных историй», о его многолетних хождениях в Монголию и Тибет в начале прошлого века, рассказанных им своим землякам-забайкальцам по возвращении.

\section{«Устные истории» паломника Бато Бадмаева}

Бадма-Базар Намсараев, сельский учитель бурятского языка и литературы Судунтуйской средней школы Агинского района Читинской области, в 1968 г. записал рассказы местного старейшины Бато Бадмаева (на момент интервью ему было 86 лет) о его многолетнем путешествии в Монголию и Тибет, которое он совершил в молодые годы в начале XX в. в группе со своими земляками вместе с ламами Агинского дацана. Опубликованные на бурятском языке в местной газете в серии очерков, эти записи на бурятском языке были опубликованы в республиканской газете «Буряад Үнэн» лишь в 1994 г. ${ }^{3}$. Анализ текста и событий, упоминаемых в рассказе, позволяет предположить, что Бато путешествовал примерно с 1901 по 1904 гг., вернулся домой после 4-х лет отсутствия, что примерно на один-два года позже путешествия, предпринятого Гомбожабом Цыбиковым (с 1899 по 1902 гг.). Стоит упомянуть, что Б. Б. Барадийн также делал записи устных историй и воспоминаний о хождениях в Тибет, расспрашивая бурятских лам, вернувшихся из дальних странствий. Так, рассказ ламы Г.-Д. Зангияина о его путешествии в 1897-1904 гг. был записан Барадийным как «Заметки об увиденном бурятским ламой Гончок-Джап Зангияином, ходившим на поклонение в Тибет, Непал и Индию» [Сазыкин 1994: 33]. Поэтому благодаря инициативам таких подвижников, как Б. Б. Барадийн, Б.-Б. Намсараев, и других энтузиастов, устные истории простых лам и мирян обрели письменную форму и были сохранены для потомков.

K сожалению, не имея возможности привести перевод рассказа Бато Бадмаева целиком, я буду обращаться лишь к некоторым эпизодам его повествования, вызывающим особый интерес в силу интересных

3 Записи бесед с Бато Бадмаевым были переизданы в 2012 г. в составе сборника сочинений Б.-Б. Намсараева [Намсараев 2012: 56-73]. 
деталей, включая полуфантастические события, случавшиеся с путешественниками в дальних краях.

Итак, Бато в девятнадцатилетнем возрасте отправился в паломническую поездку в группе тридцати лам, из коих 23 были юные послушники хувараки, и еще трое были мирянами, включая самого Бато. Он уже был знаком с некоторыми ламами, так как в свое время в возрасте 12-13 лет провел около года в Агинском дацане, обучаясь монгольской грамоте у эмчи-ламы, которому отец Бато в качестве оплаты привозил раз в месяц коровье стегно (монг. гуя) за обучение и постой своего сына. Интересно, как Бато описывает иерархию и организацию внутри группы пилигримов: среди лам, отправившихся в поездку, был гэбиэ эмчи-лама, чтобы врачевать недуги в путешествии; самым старшим был габжа-лама 4 , который «управлял всеми нами и наставлял» (бур. заабарилжа). По его наставлению паломники должны были читать молитвы во время пешего пути. Остальные пять лам должны были приглядывать за $x y$ вараками, распределив их по группам по количеству котлов для варки еды и чая.

Отметим, что речь идет о пешем (бур. ябаган) паломничестве, как наиболее добродетельном в силу тяжести физических испытаний, поэтому все вещи, необходимые для группы в путешествии: немного одежды, несколько котлов для варки еды, провизия, подношения для монастырей, российские и китайские маняад (искаж. 'монеты'), - все паломники несли на своих плечах, не используя вьючных лошадей, распределив груз между собой. Бато, по его словам, нес вес «более двух пудов» (около 32 кг $)^{5}$. Включение в состав паломников нескольких молодых сильных мужчин-мирян было оправдано, так как при распределении обязанностей в походе они могли нести с собой оружие и использовать его в случае отражения нападения на группу, а также могли охотиться для пополнения запасов, что было запрещено ламам по законам винаи 6 .

${ }^{4}$ Габжа лама (гэбии лама) - лама, обладающий ученой степенью в области буддийской философии.

${ }^{5}$ Из текста не ясно, «два пуда» груза приходились на всю группу или на одного Бато.

${ }^{6}$ Виная - свод правил и распорядка буддийской монашеской общины.
По словам Бато, паломники все же пользовались оказией, если кто-то мог подвезти их или хотя бы их поклажу, чтобы «сократить путь» (бур. газараа хороожо).

Естественно, что Бато в своих воспоминаниях уделяет много внимания физическим телесным испытаниям, которым подвергались пилигримы: как мокли под холодными дождями и студеным градом, замерзали в снежных бурях, изнывали от жары и жажды, как по несколько дней шли впроголодь, не имея возможности сварить себе горячий чай и еду. Тем не менее Бато с гордостью заключает: «Все стерпели, должны были вынести все трудности, стиснув зубы». По накалу эмоций в описании деталей перенесенных физических лишений рассказ Бато больше близок сказаниям Бааза-багши, нежели записям Г. Цыбикова, условия путешествия которого были более привилегированными, как пишет сам Г. Цыбиков, «на четырех наемных верблюдах» [Цыбиков 1991: 37], и менее изнуряющими.

Достигнув очередного монастыря после длинного пешего перехода, паломники подолгу отдыхали, вплоть до месяца и больше, набирались сил и занимались починкой истрёпанной одежды и перелицовкой изношенной обуви (монг. гутул). Тут Бато упоминает об одной детали, которая интересна с этнографической точки зрения: еще будучи дома, он запасся несколькими парами кожаных простёганных подошв (монг. ула), которые он менял на прохудившихся гутулах. Поэтому пройденные расстояния он оценивает в количестве подошв, которые ему пришлось сменить в пути: «Как много подошв мы износили (бур. элээгэ), пока проходили широкие долины, реки, горы, покрытые белыми снегами, переходы через ущелья и низины!». Так, расстояние от Агинска до Лаврана он оценил в двенадцать пар подошв, которые он протер до дыр. Примечательно, что в контексте существования уже известных мер измерения расстояний во Внутренней Азии с использованием вьючных животных: расстояние дневного перехода на лошади, дневного перехода на верблюдах в составе каравана, на оленях, на тележке запряжённой быками и прочее, эта субъективная мера по стертой паре обуви относится к одной из новых, ранее не 
описанных в литературе о паломничестве модальностей пешего передвижения на дальние расстояния.

О другом известном способе измерения расстояния пешими паломниками - полным простиранием тела по земле с вытянутыми руками (монг. һунажа мургэхэ) Бато упоминает в своем рассказе, в эпизоде, когда группа уже подошла ближе к Лхасе, и

«...своими глазами с восхищением мы взирали на сияющие на солнце золотые ганжарыl $^{7}$ на крышах Поталы (бур. Будала) дворца Далай ламы. Из последних сил, как бы мы ни устали, при виде Лхасы радость переполнила нас. Остаток пути уже стертыми в кровь босыми ногами мы прошли һунажа мургэжэ (полными простираниями)», - как и полагалось паломникам, прибывшим на святую землю [Намсараев 2012: 61].

В Лхасе Бато и его спутники нашли своих земляков лам Агинского и Цугольского дацанов, которые жили здесь в тибетских монастырях уже долгое время. Сам Бато нашел своего родственника дорамба-ламу ${ }^{8}$, у которого он прожил около трех лет. За это время он выучил тибетский язык, научился немного читать и писать на тибетском. Из тридцати трех человек в обратный путь по прошествии трех лет назад домой отправились лишь пять человек: двое лам и трое мирян, включая самого Бато. Остальные ламы и хувараки остались с другими бурятскими ламами из агинских, хоринских и селенгинских земель, которые приходили в Тибет в те годы «многим числом учиться высшим ламским знаниям» (бур. ламым дээдэ эрдэмтэ).

Подытоживая свой опыт пребывания в Тибете, Бато заключает:

«Во многих дацанах и монастырях побывал на поклонении. Повидал, как живут тибетцы, как отдыхают и работают, восхитился их нравам и привычкам (бур. ёһо заншалтай зон даa!).

${ }^{7}$ Ганжар - архитектурные украшения заостренной конической формы, покрытые золотом, на крышах буддийских монастырей.

8 Дорамба-лама - лама, обладающий второй степенью (дорамба) из пяти ученых степеней в системе буддийского образования.
Были и небылицы «устных историй» паломников

Особенно тепло Бато в своих рассказах отзывается о добрых людях, встретившихся на пути паломников в дальних землях: как милосердны они были в большинстве своем к странникам, как вовремя их советы помогали и даже спасали жизни чужеземцев в незнакомых краях. Так, где-то в Монголии паломники остановились у одной семьи. Хозяйка дома, второпях налив всем в пиалы домашнего напитка тараг ${ }^{9}$, поспешила к своему скоту, предложив гостям угоститься и отдохнуть в ее отсутствие. Утолив жажду и напившись досыта напитка, гости открыли шкафчик для еды (бур. тэбшээ), где к своей большой радости обнаружили в большой чаше куски свежесваренного мяса. Порезав мясо на мелкие кусочки, гости поделили все поровну - а речь идет о гостях общей численностью в 33 человека! - так что всем хватило положить понемногу мяса в горячий чай и насытиться. На сытый желудок гости хорошо выспались, и к вечеру, когда хозяева вернулись, путники, поблагодарив гостеприимных хозяев, вновь отправились в путь. «Да умножатся Ваши богатства, да изменится Ваша жизнь к лучшему!», - пожелал на прощание старший габжа-лама хозяевам.

В другом случае, свидетелем которого был Бато, обогнав одного старого ламу по дороге, один мирянин, ехавший на телеге, отказал ему в просьбе подвезти его немного и дать передохнуть его натруженным ногам. Разгневанный лама успел справить нужду на заднее колесо телеги жестокосердного мирянина. После этого, подождав, как телега, грохоча, укатилась вперед на некоторое расстояние, лама грозно взмахнул посохом и ударил им несколько раз об землю, прокричав при этом магическое заклинание (бур. жадхын хараал). Примкнув к бурятским паломникам, лама вместе с группой перешел через перевал, и там путники, к своему удивлению, увидели того самого возницу полностью обескураженным и подавленным, стоящим у сломанной телеги, у которой отскочило переломанное колесо то самое колесо...

Благодаря помощи местных жителей паломники смогли перейти пустыню Гоби без

9 Из текста не ясно, «два пуда» груза приходились на всю группу или на одного Бато. 
потерь - они снабдили путников емкостями для воды. В Амдо в предгорьях, как повествует Бато, местные семьи зарабатывали тем, что давали передохнуть пилигримам, стирали и чинили их одежду перед тяжелым многодневным переходом через горную гряду. Так, семья кукунорских монголов, у которой остановились бурятские паломники, дала им ценные советы, как миновать опасности, подстерегавшие их на долгих горных перевалах. При этом каждый из группы получил берестяной короб и длинный шест со следующими словами:

«На перевале, когда остановитесь на ночлег, не ложитесь в ряд, а ложитесь в круг, головами внутрь круга, ногами наружу. Не шумите и не разговаривайте! К ночи появится зверь человеческого вида алмас, все его тело покрыто желто-коричневой шерстью сбившейся в клочья. Он начнет обходить вас кругами и обнюхивать. В этот момент вы должны водрузить берестяной короб на деревянную палку и начать крутить с шумом, чтобы отпугнуть его. Если ляжете в ряд, то он придет назад с дубиной и забьет вас до смерти, как случалось уже много раз. Как только спуститесь с перевала, у подножия увидите небольшое поселение из двух семей, у них и оставите короба с прутьями».

Бато и его спутники сделали все точно так, как сказали хозяева: на высокой точке перевала расположившись на ночлег кругом, паломники замерли в ожидании невиданного существа алмас. Из-за высокогорья и разреженного воздуха (бур. агаар шэнгэн) люди чувствовали себя ослабленными и утомленными. Бато продолжает:

«Как нас и предупреждали, тот самый зверь появился из темноты. Замерев от страха, мы начали крутить берестяные короба на шестах. Алмас обошел вокруг нас несколько раз, он был так близко, что мы могли чувствовать его смрадное дыхание. Когда он удалился, мы спешно покинули место, чтобы уйти как можно дальше. Скорее всего, алмас ушел за дубиной, чтобы, вернувшись, прибить нас! Так мы спаслись и начали спуск вниз. Внизу у подножия горы, как нам и говорили, жили две тибетские семьи, у которых мы и оставили короба с шестами. Взамен каждому из нас вручили по два тонких прута, чтобы в дальнейшем пути мы могли этими прутами отгонять злых тибетских псов. При этом нам объяснили, что бить этих псов по спине нельзя - прутья переломаются, а надо было, как ташуром-плеткой, бить по бокам. С этими прутьями в руках так мы и дошли до Лхасы. Ох, какие тибетские собаки лютые, огромные, размером с двухгодовалого теленка, скалились и бежали за нами с лаем» [Намсараев 2012: 61].

Примечательно, что паломническое путешествие Бато не ограничивается лишь Тибетом. На обратном пути он и его спутники остановились в Урге (Их Хурээ) и пробыли там почти год. Из ургинских воспоминаний примечательны два эпизода из его рассказа: благословение Богдо-хана Джебцзун-Дамба-хутухты и «разоблачение» «плачущего Будды», на которых я остановлюсь подробнee.

\section{Паломники в Урге}

Паломничество в Ургу на поклон к Богдо-гегену имело широкий пан-монгольский характер и было более доступным для больших масс верующих, приходящих со всей Монголии, Внутренней Монголии, Забайкалья и Калмыкии, в отличие от долгого путешествия к монастырям Амдо (Лабран и Гумбум) или Тибета. Благодаря десяткам описаний российских и западных путешественников, торговцев, дипломатов и миссионеров середины XIX - начала XX вв. (к примеру [Тимковский 1827; Позднеев 1896, 1898; Цыбиков 1919; Жамцарано 2001; Ramstedt 1978; Andrews 1921; Geleta 1936; и др.]), а также устным преданиям перед нами предстает детально описанная картина широкого народного поклонения Богдо-гегену. Однако все эти описания представляют картину глазами сторонних наблюдателей, в то время как Бато, как непосредственный участник, описывает столпотворение у дворца Богдо-гегена:

«Три дня я пытался протолкнуться сквозь толпу в очереди за благословением к Богдо-гегену. Но меня все время оттирали и я не мог даже приблизиться. Лишь на четвертый день мне удалось получить святейшее благословение (монг. адис) к моему успокоению» [Намсараев 2012: 62].

Напомним, что паломников пускали к Богдо-гегену лишь в утренние часы, и 
к 11 утра всех страждущих получить его благословение уже выгоняли со двора Богдо-гегена. Позже, начиная с 1910-х гг., когда уже тысячи паломников осаждали двор святейшего, было внесено одно новшество - из окна дворца был спущен короткий канат. Встав на колени, верующие должны были дотрагиваться до конца каната, искренне веря, что Богдо-геген держится за другой конец каната и тем самым дает свое прямое благословение. Бато еще не застал это новшество, так как он находился в Урге примерно в 1904-1905 гг.

В эпизоде разоблачения «плачущего Будды» Бато рассказывает, что в одном из небольших монастырей ( $c$ мэ), недалеко от монастырского комплекса Гандан, был обычай вывозить на люди к паломникам большую деревянную статую Будды ${ }^{10}$. По словам Бато, верующие неистово молились и отдавали последнее, так как становились свидетелями чуда - во время объезда паломников статуя Будды начинала проливать слезы, видя множество больных, бедных страждущих паломников. Бато продолжает:

«Ламы кричали толпе: „Ваши грехи велики! Видите, бурхан плачет из сострадания к вам? Молитесь усердно и делайте щедрые подношения (бур. үргэл мүргэл ехээ хэг$m b l)$. Не жалейте своего богатства [на благое дело]!"е».

Молящиеся отдавали все, что было у них, вплоть до одежды, и уходили чуть ли не в исподнем (бур. нюсэгэн тооной). Бато и несколько из его спутников-мирян стали служить при этом храме в качестве охраны, разделенные на группы по десять человек, охранники должны были следить за порядком среди верующих и отгонять паломников по пути следования статуи. В один из дней Бато сказали охранять саму статую, то есть находиться в непосредственной близости к ней. Тут-то Бато и увидел, что внутри статуи, занавешенной длинными одеждами, сидел лама, который обильно смачивал водой глаза бурхана изнутри. Бато не стал уточнять в своем рассказе, что он сделал или сказал, увидев

${ }^{10} \mathrm{~K}$ сожалению, мне пока не удалось идентифицировать, о каком сүмэ недалеко от Гандана идет речь. такое надувательство, лишь добавил, что вскоре обман был раскрыт. И, как говорили люди, ламы-мошенники, обиравшие народ с помощью уловок, были пойманы, а одежду и подношения раздали верующим.

Путешествия и приключения Бато были далеки от завершения после нескольких лет жизни в Лхасе и Урге. Вернувшись на родину, он подрядился вместе со своими земляками участвовать в строительстве читинского участка железной дороги, ведшей в Харбин. Отправившись в Харбин, он оказался в разных перипетиях и опасных ситуациях, в коих участвовали разные жители Хулунбуира: китайцы, дауры, барга-монголы и русские казаки. Но этим приключениям посвящены другие рассказы Бато, где он не менее увлекательно живописует встречи с даурской шаманкай, с баргинскими бандитами, русскими фальшивомонетчиками, промышлявшими вдоль Китайско-Восточной железной дороги (КВЖД). Но, пожалуй, самое большое умение, которое он приобрел за годы скитаний и путешествий по Внутренней Азии, по его словам, - это умение находить воду (бур. уhанай hyдал урадхал) с помощью лозы, которому он обучился под Харбином, случайно попав в бригаду китайцев, рывших колодцы. Эта способность стала его профессией в поздние годы во времена советской власти, за что его земляки уважительно стали называть его «Бато худагша» (Бато - искатель воды). По всем селам Агинского округа до сих пор люди пользуются колодцами с

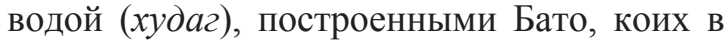
общей численности около трехсот. За это умение чувствовать и видеть подземные потоки воды его особенно почитали ламы и называли Бато «живым воплощение водных божеств луусад» (амиды лусад) [Намсараев 2012: 72]. Так подытожил серию своих очерков о странствиях и приключениях Бато его интервьюер - сельский учитель Бадма-Базар Намсараев.

\section{Заключение}

Рассказы Бато, записанные в жанре «устных историй», являются уникальным источником сведений о широкой практике бурятского паломничества к буддийским святыням Внутренней Азии в начале прошлого века, рассказанные самим участником - актором паломничества, 
а не сторонним наблюдателем. Несмотря на незамысловатость повествования и их фольклорный характер с полуфантастическими элементами, эти рассказы несут в себе ценные сведения, которые были упущены в путевых дневниках других профессиональных путешественников и буддийских священнослужителей. В силу опыта именно пешего паломничества, рассказы Бато описывают инфраструктуру, возникшую вдоль трансграничного

\section{Литература}

Ванчикова 1995 - Ванчикова Ц. П. Монголоязычные биографии бурятских лам // Средневековая культура Центральной Азии: письменные источники. Улан-Удэ: Изд-во БНЦ CO PAH, 1995. C. 33-43.

Дугар-Нимаев 1974 - Дугар-Нимаев Ц. А. О жанре хождений в бурятской литературе XIX века // Проблемы алтаистики и монголоведения. Вып. 1. Сер. литературы, фольклора и истории. Элиста: КНИИЯЛИ, 1974. С. $147-159$.

Жамцарано 2001 - Жамцарано Ц. Путевые дневники: 1903-1907 гг. / отв. ред. Ц. П. Ванчикова, сост.: В. Ц. Лыксокова, Ц. П. Ванчикова, И. В. Кульганек. Улан-Удэ: Изд-во БНЦ СО РАН, 2001. 382 с.

Намсараев 2012 - Намсараев Б.-Б. Худагша Батын ушаралта ябадалнуудһаa // Минии шүлэг - бодолойм хүлэг, мини нютаг наһанайм түшэг. Улаан-Үдэ: Буряадай гүрэнэй университедэй хэблэл, 2012. С. 5673. (На бур. яз.)

Позднеев 1897 - Позднеев А. М. Сказание о хождении в тибетскую страну Малодербетского База-бакши. СПб., 1897. XVIII+260 с.

Позднеев 1896 - Позднеев А. М. Монголия и монголы. Результаты поездки в Монголию, исполненной в 1892-1893 гг. А. Позднеевым. [В 2 тт.]. Т. 1. Дневник и маршрут 1892 года. СПб.: Тип. Имп. Академии наук, 1896. XXX, 697 с. Т. 2. Дневник и маршрут 1893 года. СПб.: Тип. Имп. Академии наук, 1898. XXX, 517 c.

Сазыкин 1988 - Сазыкин А. Г. Каталог монгольских рукописей и ксилографов Института востоковедения Академии Наук СССР. Т. І / отв. ред. Д. Кара. М.: ГРВЛ, 1988. 508 с.

Сазыкин 1989 - Сазыкин А. Г. Описание Тибета, составленное в XVIII в. бурятским паломником Дамба-Доржи Заяевым // Страны и народы Востока. Вып. XXVI. Средняя и Центральная Азия (География, этнография, маршрута, призванную обслуживать как пеших паломников, так и караваны: те самые семьи монголов и тибетцев, которые обеспечивали паломников берестяными коробами с шестами, прутьями, емкостями для воды для перехода пустыни и т. д. Переиздание рассказов Бато Бадмаева о хождениях в Тибет и Монголию дало возможность ввести в научный оборот этот уникальный источник и сделать его доступным для широкой публики.

история). М.: Наука, ГРВЛ, 1989. С. 117-125. Сазыкин $1994-$ - Сазыкин А. Г. Описание путешествий в литературном наследии монгольских народов // Страны и народы Востока. Вып. XXVIII. География. Этнография. История. Культура. СПб.: Центр «Петербургское востоковедение», 1994. С. 26-35.

Тимковский 1827 - Тимковский Е. Ф. Путешествие в Китай через Монголию в 1820 и 1821 годах Е. Ф. Тимковского [Атлас] [Voyage a Peking, a travers la Mongolie, en 1820 et 1821, par M. Timkovski. Atlas]. Paris: A la librairie oriental de Dondey-Dupre pere et fis, 1827. 32 p. (На франц. яз.)

Черемисов 1972 - Черемисов К. М. Бурятско-русский словарь / гл. ред. К. М. Черемисов. М.: Сов. энциклопедия, 1972. 803 с.

Цыбиков 1991 - Цыбиков Г. Ц. Буддист-паломник у святынь Тибета // Цыбиков Г. Ц. Избранные труды. Т. 1. Новосибирск: Наука, 1991. 256 c.

Цыбиков 1919 - Цыбиков Г. Ц. Буддист-паломник у святынь Тибета. Издание Русского Географического Общества. Петроград, 1919. $482 \mathrm{c}$.

Andrews 1921 - Andrews R. Ch. Across Mongolian Plains: A Naturalist's Account of China's "Great Northwest". D. Appleton and Company New York: London, 1921. 304 p.

Charleux 2015 - Charleux I. Nomads on Pilgrimage: Mongols on Wutaishan (China), 1800-1940. Vol. 33. Leiden: Brill's Inner Asian Library, 2015. 472 p.

Geleta 1936 - Geleta J. The new Mongolia. London, Toronto: W. Heinemannn ltd., 1936. 276 p.

Pratt 2008 - Pratt M. L. Imperial Eyes: Travel Writing and Transculturation. Second ed. New York: Routledge, 2007. 276 p.

Ramstedt 1978 - Ramstedt G. J. Seven Journeys Eastward 1898-1912. Among the Cheremis, Kalmyks, Mongols and in Turkestan and to Afghanistan. Bloomington: The Mongolia Society, 1978. 277 p. 


\section{References}

Andrews R. Ch. Across Mongolian Plains: A Naturalist's Account of China's 'Great Northwest'. New York, London: D. Appleton and Company, 1921. 304 p. Available at: https://library. um.edu.mo/ebooks/b28020868.pdf (accessed October 1, 2020). (In Eng.)

Charleux I. Nomads on Pilgrimage: Mongols on Wutaishan (China), 1800-1940. Ser.: Brill's Inner Asian Library, 2015. Vol. 33. 472 p. (In Eng.)

Cheremisov K. M. (ed.) Buryat-Russian Dictionary. Moscow: Sovetskaya Entsiklopediya, 1972. 803 p. (In Bur. and Russ.)

Dugar-Nimaev Ts. A. The genre of pilgrimage memoirs in $19^{\text {th }}$-century Buryat literature. In: Issues of Altaic and Mongolian Studies. Vol. 1. Ser.: Literature, Folklore and History. Elista: Kalmyk Research Institute of Language, Literature and History, 1974. Pp. 147-159. (In Russ.)

Geleta J. The New Mongolia. London, Toronto: W. Heinemannn Ltd., 1936. 276 p. (In Eng.)

Namsaraev B.-B. Khudagsha Batyn usharalta yabadalnuudhaa. In: Minii shyleg — bodoloym khyleg, mini nyutag — nahanaym tysheg. UlanUde: Buryat State University, 2012. Pp. 56-73. (In Bur.)

Pozdneev A. M. Mongolia and the Mongols: Summarizing Results of the 1892-1893 Journey to Mongolia. In 2 vols. Vol. 1: Diary and Route of the Year 1892. St. Petersburg: Imperial Academy of Sciences, 1896. XXX, 697 p. Vol. 2: Diary and Route of the Year 1893. St. Petersburg: Imperial Academy of Sciences, 1898. XXX, 517 p. (In Russ.)

Pozdneev A. M. The Story of Ven. Baga Dorbet Baza Bakshi's Pilgrimage to the Land of Tibet. St. Petersburg, 1897. XVIII+260 p. (In Russ.)

Pratt M. L. Imperial Eyes: Travel Writing and Transculturation. $2^{\text {nd }}$ ed. New York: Routledge, 2007. 276 p. (In Eng.)

Ramstedt G. J. Seven Journeys Eastward, 1898-1912: Among the Cheremis, Kalmyks,
Mongols and in Turkestan and to Afghanistan. Bloomington: The Mongolia Society, 1978. 277 p. (In Eng.)

Sazykin A. G. Description of Tibet made by the Buryat pilgrim Ven. Damba-Dorzhi Zayaev in the $18^{\text {th }}$ century. In: Countries and Peoples of the East. Vol. XXVI: Soviet and Foreign Central Asia. Geography, Ethnography, History. Moscow: Nauka - GRVL, 1989. Pp. 117-125. (In Russ.)

Sazykin A. G. Institute of Oriental Studies, USSR Academy of Sciences: Catalogue of Mongolian Manuscripts and Xylographs. Vol. I. D. Kara (ed.). Moscow: Nauka - GRVL, 1988. 508 p. (In Russ.)

Sazykin A. G. Pilgrimage memoirs in the literary heritage of Mongolic peoples. In: Countries and Peoples of the East. Vol. XXVIII: Geography, Ethnography, History, Culture. St. Petersburg: Peterburgskoe Vostokovedenie, 1994. Pp. 26-35. (In Russ.)

Timkovsky E. F. Voyage a Peking, a travers la Mongolie, en 1820 et 1821, par M. Timkovski. Atlas (E. Timkovsky's Travel to China via Mongolia in 1820 and 1821). Paris: A la librairie oriental de Dondey-Dupre pere et fis, 1827. (In Fr.)

Tsybikov G. Ts. A Buddhist Pilgrim at the Shrines of Tibet. Edition by the Russian Geographical Society. Petrograd, 1919. 482 p. (In Russ.)

Tsybikov G. Ts. A Buddhist Pilgrim at the Shrines of Tibet. In: Tsybikov G. Ts. Selected Works. Vol. 1. Novosibirsk: Nauka, 1991. 256 p. (In Russ.)

Vanchikova Ts. P. Mongolian-language biographies of Buryat clerics. In: Medieval Culture of Central Asia. Written Sources. Ulan-Ude: Buryat Scientific Center (Sib. Branch of RAS), 1995. Pp. 33-43. (In Russ.)

Zhamtsarano Ts. Travel Diaries: 1903-1907. Ts. Vanchikova (ed.), V. Lyksokova, Ts. Vanchikova, I. Kulganek (comps.). Ulan-Ude: Buryat Scientific Center (Sib. Branch of RAS), 2001. 382 p. (In Russ.) 